\title{
Volatile concentrate from the neotropical moss Neckeropsis undulata (Hedw.) Reichardt, existing in the brazilian Amazon
}

\author{
Thyago G. Miranda' ${ }^{1}$, Raynon Joel M. Alves ${ }^{1}$, Ronilson F. de Souza², José Guilherme S. Maia ${ }^{3}$, \\ Pablo Luis B. Figueiredo ${ }^{2^{*}}$ (ID and Ana Cláudia C. Tavares-Martins ${ }^{1,2}$
}

\begin{abstract}
Background: Many natural compounds have been identified and synthesized by the advancement of bryophytes phytochemistry studies. This work aimed to report the composition of Neckeropsis undulata (Hedw.) Reichardt moss volatiles, sampled in the Combú Island, Belém city, Pará state, Brazil. The volatile concentrate of N. undulata was obtained by a simultaneous distillation-extraction micro-system, analyzed by GC and GC-MS, and reported for the first time.

Results: Ten compounds were identified in the volatile concentrate, corresponding to $91.6 \%$ of the total, being 1-octen-3-ol (35.7\%), a-muurolol (21.4\%), naphthalene (11.3\%), and $n$-hexanal (10.0\%) the main constituents. Most of the constituents of the $\mathrm{N}$. undulata volatile concentrate have been previously identified in other mosses, and liverworts spread wide in the world.

Conclusions: 1-Octen-3-ol, $n$-hexanal, 2-ethylhexanol, isoamyl propionate, and octan-3-one are already known metabolic products obtained from enzymatic oxidation of polyunsaturated fatty acids, belonging to the large family of minor oxygenated compounds known as oxylipins. The knowledge of the composition of volatiles from moss $N$. undulata could contribute to the Neckeraceae species' chemotaxonomy.
\end{abstract}

Keywords: Neckeraceae, Volatile concentrate, 1-octen-3-ol, a-muurolol, n-hexanal

\section{Background}

Bryophytes are small terrestrial spore-forming green plants, phylogenetically placed between vascular plants and algae, and comprises about 22,000 species worldwide. They are most diverse in the tropics and fit in a general pattern of various groups of organisms, increasing species toward the equator line. Mosses (Bryophyta), liverworts (Marchantiophyta), and hornworts (Anthocerotophyta) compose the three lineages of bryophytes. The mosses are estimated to include about 12,700 species [1].

\footnotetext{
${ }^{*}$ Correspondence: pablo.figueiredo@uepa.br

${ }^{2}$ Departamento de Ciências Naturais, Universidade do Estado do Pará,

Belém, PA 66050-540, Brazil

Full list of author information is available at the end of the article
}

Brazil's bryophyte flora comprises 1524 species, of which 880 are mosses, 633 liverworts, and 11 hornworts. The Atlantic Forest biome has the most significant number of species (1337), followed by the Amazon (570) and the Cerrado (478) biomes [2].

Neckeraceae, a moss family with about 200 species, belongs to the order Hypnales of pleurocarpous mosses. Neckeropsis undulata (Hedw.) Reichardt [syn. Daltonia undulata (Hedw.) Arn., Distichia undulata (Hedw.) Brid., Eleutera jamaicensis Stuntz, Fontinalis crispa Sw., Neckera amazonica Mitt., N. undulata Hedw., Pilotrichum undulatum (Hedw.) P. Beauv.], a neotropical moss species widespread in all Americas, is light to a dark green plant, stems $5.0 \mathrm{~mm}$ long and perpendicular to the substrate, leaves ovate-ligulate $2.0 \mathrm{~mm}$ long to $1.0 \mathrm{~mm}$ wide, 
forming mats, frequently occurring on trunks of shrubs and trees [3-5].

Bryophytes have no physical defenses against any type of threat and, in general, are not attacked by insects and small animals. These plants emit scents such as sweetwoody, sweet-mossy, turpentine, carrot-like, mushroomy, and seaweed-like. However, bryophytes' volatiles chemistry is not well known because they are small species and challenging to collect. Besides, they are considered of little nutritional value to humans. However, some mosses have been widely used as medicinal plants in China to cure burns, bruises, external wounds, snake bite, fractures, and convulsions [6, 7].

The essential oil composition of some moss species has been previously reported. In the oils of Hylocomium splendens (Hedw.) Schimp. and Leucodon sciuroides (Hedw.) Schwagr., existing in Turkey, the primary constituents were $\beta$-pinene and $\alpha$-pinene, and nonanal and heptanal, respectively [8]. The presence of sesquiterpene and diterpene hydrocarbons in the oils of six mosses species from Ecuador were reported: in Breutelia tomentosa (Sw. ex. Brid.) A. Jaeger the primary constituents were epizonarene and $\alpha$-selinene; in Leptodontium viticulosoides (P. Beauv.) Wijk \& Margad. were $\alpha$ - and $\beta$-selinene; in Macromitium perreflexum Steere were selina-3,11-dien-6- $\alpha$-ol and curcuphenol; in Campylopus richardii Brid. were epi- $\alpha$-muurolol and $\alpha$-cadinol; in Rhacocarpus purpurascens (Brid.) Paris. were $\alpha$-cadinol and $\alpha$-santalene, and in Thuidium peruvianum Mitt. were phytol and valerenol [9]. Phytol and 1-octen-3-ol were the primary components obtained in the oil of the moss Rhodobryum ontariense Kindb. From Serbia [10]. Linoleic acid, arachidonic acid, and eicosapentaenoic acid are common in bryophytes, and they act as biosynthesis precursors of some mushrooms smelling eight-carbon alcohols and ketones, metabolites known as oxylipins, such as 1-octen-3-ol and octan-3-one [11-13].

Essential oils analysis of Neckera complanata (Hedw.) Huebener and N. crispa Hedw., species also occurring in Turkey and belonging to the Neckeraceae have been described. $\beta$-Phellandrene, camphene, $\gamma$-bisabolene, and $\alpha$-pinene were the main compounds in the $N$. complanata oil, while octan-3-one and limonene predominated in the oil of N. crispa [14].

Few chemical and biological studies have been done with bryophytes in Brazil. Organic extracts of 25 bryophytes from the Brazilian Amazon, with solvents of different polarities, were tested against 13 pathogenic bacteria of a broad general spectrum [15]. The antibacterial activity of ethanol extract of the moss Octoblepharum albidum from Crato, Ceará state, Brazil, alone and in association with aminoglycosides, was determined against bacterial strains, resulting in significant and similar inhibitory activity for Escherichia coli ATCC 25,922 and Klebsiella pneumoniae ATCC 33,018. Also, phytochemical screening was performed with the same extract to identified the bioactive compounds [16]. Chemical diversity of the secondary metabolites of 12 populations of Syzygiella rubricaulis (Nees) Stephani (Jamesoniellaceae, Marchantiophyta) from the high tropical mountains of Mexico, Venezuela, Ecuador, and Brazil was performed. Sesquiterpenoids, diterpenoids, and long-chain hydrocarbons predominated in the $\mathrm{CHCl}_{2}$ extracts of the 12 populations of S. rubricaulis [17]. To the best of our knowledge, no work with essential oils or volatile concentrates of bryophytes has been previously published in Brazil.

This work aimed to report the volatile composition from the moss Neckeropsis undulata (Hedw.) Reichardt, which occurs in the Brazilian Amazon, in order to extend the chemotaxonomic knowledge of this species.

\section{Experimental}

\section{Plant material and extraction procedure}

Neckeropsis undulata (Hedw.) Reichardt (Neckeraceae) is a native and non-endemic moss species, with occurrence throughout all Brazil regions [5] and easily found in the Brazilian Amazon. The samples of $N$. undulata were collected in a floodplain area close to Belém, Pará state, Brazil, on the trunk of live cocoa trees, using techniques proposed by Yano (1984) [18]. Different bryophytes can occur together, and this species was separated using tweezers with magnifying glasses, considering its gametophyte and sporophyte phases. The botanical identification was carried out by Prof. Ana Cláudia Martins, a Bryophytes specialist from Departamento de Ciências Naturais, Universidade do Estado do Pará, Belém, Pará state, Brazil. The moss sample (100 g) was air-dried for three days, and its volatile concentrate was obtained by micro hydrodistillation-extraction in a Likens-Nickerson apparatus (25 g, $2 \mathrm{~h}$, duplicate) [19], using n-pentane $(3 \mathrm{~mL})$ as the solvent.

\section{Volatile concentrate analysis}

The volatile concentrate of $N$. undulata was submitted to GC and GC-MS analysis. It was performed on a GCMS-QP2010 Ultra system (Shimadzu Corporation, Tokyo, Japan), equipped with an AOC-20 i autoinjector and the GCMS-Solution software containing the NIST and FFNSC 2 libraries [20, 21]. A Rxi-5 ms (30 $\mathrm{m} \times 0.25 \mathrm{~mm} ; 0.25 \mu \mathrm{m}$ film thickness) silica capillary column (Restek Corporation, Bellefonte, PA, USA) was used. The conditions of analysis were as follows. Injector temperature: $250{ }^{\circ} \mathrm{C}$; Oven temperature programming: $60-240{ }^{\circ} \mathrm{C}\left(3{ }^{\circ} \mathrm{C} / \mathrm{min}\right)$; Helium as the carrier gas, adjusted to a linear velocity of $36.5 \mathrm{~cm} / \mathrm{s}(1.0 \mathrm{~mL} / \mathrm{min})$; split mode 
injection (split ratio 1:20) of $1.0 \mu \mathrm{L}$ of the $n$-pentane solution; ionization by electronic impact at $70 \mathrm{eV}$; ionization source and transfer line temperatures of 200 and $250{ }^{\circ} \mathrm{C}$, respectively. The mass spectra were obtained by automatic scanning every $0.3 \mathrm{~s}$, with mass fragments in the range of $35-400 \mathrm{~m} / \mathrm{z}$. The retention index was calculated for all volatile components using a homologous series of C8-C40 n-alkanes (Sigma-Aldrich, Milwaukee, WI, USA), according to the linear equation of Van Den Dool and Kratz [22]. Individual components were identified by comparing their retention indices and mass spectra (molecular mass and fragmentation pattern) with those existing in the GCMS-Solution system libraries [20, 21, $23]$. The quantitative data regarding the volatile constituents were obtained using a GC 2010 Series, operated under similar conditions to those of the GC-MS system. The relative amounts of individual components were calculated by peak-area normalization using a flame ionization detector (GC-FID). The analyses were performed in duplicate.

\section{Results and discussion}

The yield of the volatile concentrate of the $N$. undulata moss was $0.25 \%$. Thirteen constituents are listed in Table 1, comprising $99.8 \%$ of the total concentrate. 1-Octen-3-ol (35.7\%), $\alpha$-muurolol (21.4\%), naphthalene $(11.3 \%)$, and hexanal $(10.0 \%)$ were the primary components.

The addition of molecular oxygen to polyunsaturated fatty acids and the transformations of the resulting hydroperoxides leads to the production of a large family of minor oxygenated compounds known as oxylipins. The main constituent of the volatile concentrate on $N$. undulata was 1-octen-3-ol (35.7\%). It is allyl alcohol known as mushroom alcohol, and an oxylipin produced by enzymatic oxidation and cleavage of the linoleic, arachidonic, and eicosapentaenoic acids. In nature, the 1-octen-3-ol is indicated as a signaling molecule in plant cellular responses, plant-herbivore interactions, and plant-plant interactions $[11,13,24]$. In the oil of the moss Rhodobryum ontariense Kindb. from Serbia, 1-octen-3-ol has been identified as the secondary constituent, following the diterpene phytol, which was the main component [10]. The thalli of the liverwort Marchantia polimorpha emitted high amounts of $\mathrm{C} 8$ volatiles, after mechanical wounding, mainly consisting of 1-octen-3-ol and octan3-one, which were also isolated from the $N$. undulata volatile concentrate, together with another unidentified C8 alcohol, with a low percentage. The presence of arachidonic acid or eicosapentaenoic acid seemed essential for the formation of these volatile compounds of C8-type [25].
Table 1 Constituents identified in the volatile concentrate of Neckeropsis undulata

\begin{tabular}{|c|c|c|c|}
\hline Constituents (\%) & $\mathbf{R I}_{\mathbf{C}}$ & $\mathbf{R} \mathbf{I}_{\mathbf{L}}$ & $\begin{array}{l}\text { Volatile } \\
\text { concentrate } \\
(\%)^{*}\end{array}$ \\
\hline n-hexanal & 798 & $801^{a}$ & 10.0 \\
\hline isoamyl propionate & 969 & $960^{a}$ & 1.2 \\
\hline 1-octen-3-ol & 974 & $974^{\mathbf{a}}$ & 35.7 \\
\hline unidentified 1-octen-3-ol isomer, MW 128 & 979 & & 0.6 \\
\hline octan-3-one & 983 & $979^{a}$ & 1.0 \\
\hline 2-pentylfuran & 989 & $984^{a}$ & 1.6 \\
\hline 2-ethylhexanol & 1025 & $1030^{b}$ & 2.8 \\
\hline naphthalene & 1180 & $1178^{\mathbf{a}}$ & 11.3 \\
\hline benzophenone & 1624 & $1626^{a}$ & 1.7 \\
\hline a-muurolol (=torreyol) & 1645 & $1644^{a}$ & 21.4 \\
\hline phytone & 1842 & $1841^{b}$ & 4.9 \\
\hline $\begin{array}{l}\text { unidentified oxygenated sesquiterpene, } \\
\text { MW } 222\end{array}$ & 1865 & & 2.8 \\
\hline $\begin{array}{l}\text { unidentified oxygenated sesquiterpene, } \\
\text { MW } 222\end{array}$ & 1959 & & 4.8 \\
\hline Total (\%) & & & 99.8 \\
\hline \multicolumn{4}{|c|}{$\begin{array}{l}\mathrm{RI}_{\mathrm{C}} \text { : Calculated Retention Index (Rxi-5 ms column); } \mathrm{Rl}_{\mathrm{L}} \text { : Literature Retention index } \\
\text { a } \text { Adams [23]; }{ }^{\mathrm{b}} \text { Mondello [21]; Main constituent in italics }\end{array}$} \\
\hline
\end{tabular}

The second most abundant constituent of the volatile concentrate on $N$. undulata was the oxygenated sesquiterpene $\alpha$-muurolol (21.4\%). Terpene compounds are present in little amounts in mosses when compared to liverworts [26]. $\alpha$-Muurolol has a cadinane skeleton, and it is found in liverworts and mosses. Many sesquiterpene and diterpene compounds are also identified in higher plants [6]. For example, in the liverwort Frullania brasiliensis Raddi and moss Campylopus richardii Brid. oils, the stereoisomer epi- $\alpha$-muurolol was the primary constituent, with $32.18 \%$ and $15.1 \%$, respectively $[9,27]$.

The third-highest constituent in the volatile concentrate on $N$. undulata was naphthalene $(11.3 \%)$. The hydrocarbon naphthalene has been identified in the liverworts Plagiochila subdura Inoue and Triandrophyllum subtrifidum (Hook. \& Taylor) Fulford \& Hatcher [28]. The aromatic derivatives, 3,4-dimethoxy-1,2-methylenedioxynaphthalene, 1,4-dimethoxy-1,2-methylenedioxynaphthalene, and 2,4,7-trimethoxynaphthalene were isolated from extracts of Wettsteinia inversa (Sande-Lacoste) Schiffner (syn. Plagiochila inversa Sande-Lacoste) and W. schusterana Grolle, two liverworts existing in Taiwan and New Zealand, respectively [29, 30]. Also, 1,2,3-trimethoxynaphthalene and 1,2,4-trimethoxynaphthalene were isolated from extracts of the liverwort Adelanthus decipiens sampled in the British Isles and South America [31]. 
The fourth primary constituent identified in the volatile concentrate on $N$. undulata was $n$-hexanal (10.0\%), which must have been generated from arachidonic acid or linolenic acid by the action of a lipoxygenase, as previously reported for the liverwort Marchantia polymorpha L, producing $n$-hexanal and (Z)-3-hexenal after wounded plant tissues [32]. The volatile fractions of two samples of the moss Rhodobryum giganteum (Schwaegr.) Par. from China also presented $n$-hexanal as its primary constituent, with amounts of $19.7 \%$ (Kaiyuan city, Yunnan Province) and 8.6\% (Lushui county, Yunnan Province), respectively [33].

The diterpene phytone (hexahydrofarnesyl acetone), identified in the volatile concentrate of $N$. undulata (4.9\%), is commonly found in variable amounts of mosses essential oils, such as Tortula muralis Hedw. (2.2\%), Homalothecium lutescens (Hedw.) H. Rob. (2.0\%), Hypnum cupressiforme Hedw. (3.0\%), and Pohlia nutans (Hedw.) Lindb. (3.7\%) [34], while phytol (phytone precursor) may be found in meaningful amounts in the oils of the mosses Rhodobryum ontariense (31.95\%) [10] and Thuidium peruvianum (21.7\%) [9].

2-Ethylhexanol was identified in the volatile concentrate of $N$. undulata (2.8\%) and also detected in the mosses Oxystegus tenuirostris (Hooler \& Taylor) A. Smith (4.13\%) and Eurhynchium striatum (Schreb. ex Hedw.) Schimp (5.85\%), with occurrence in Turkey [35], and Rhodobryum giganteum (1.7\%) existing in China [33]. It is assumed that 2-ethylhexanol was also generated from linoleic acid by the action of a lipoxygenase.

Benzophenone, present in small amounts in the volatile concentrate on $N$. undulata (1.7\%), was also identified in the moss essential oil of Leucodon sciuroides (0.8\%), growing in Turkey [8]. Moreover, 2-pentylfuran, another minor constituent on $N$. undulata (1.6\%), was also found in the moss Rhodobryum giganteum (0.9\%) [33].

\section{Conclusions}

In this work, the volatile composition of Neckeropsis undulata moss was reported for the first time, and it is assumed that this knowledge can contribute to a better understanding of the Brazilian bryophytes. 1-Octen3-ol, the primary constituent, is already a known metabolic product, obtained from enzymatic oxidation of polyunsaturated fatty acids. $\alpha$-Muurolol is a oxygenated sesquiterpene, with a cadinane skeleton, found in other mosses and of chemotaxonomic importance. 1-Octen3-ol, $n$-hexanal, 2-ethylhexanol, isoamyl propionate, and octan-3-one belong to the large family of minor oxygenated compounds oxylipins, generated from long-chain fatty acids.
Abbreviations

GC: Gas chromatography; GC-MS: Gas chromatography-mass spectrometry; GC-FID: Gas chromatography-flame ionization detector.

\section{Acknowledgements}

The authors would like to thank CAPES, a Brazilian Government's research funding agency, for the fellowship support.

\section{Authors' contributions}

TGM and RJMA participated in the collection and preparation of the plants, run the laboratory work, analyzed the data, and contributed to the drafted paper. RFS helped with lab work. PLBF helped with data analyses. ACCTM proposed the work plan and guided the lab work and data analysis. JGSM and PLBF drafted the manuscript. All authors read and approved final manuscript.

Funding

No financial support for this project.

\section{Availability of data and materials}

All data generated or analyzed during this study are included in this manuscript.

\section{Ethics approval and consent to participate}

Not applicable.

\section{Consent for publication}

Not applicable.

\section{Competing interests}

We declare that no competing interest.

\section{Author details}

1 Programa de Pós-Graduação em Biodiversidade e Biotecnologia, Universidade Federal do Pará, Belém, PA 66075-110, Brazil. ${ }^{2}$ Departamento de Ciências Naturais, Universidade do Estado do Pará, Belém, PA 66050-540, Brazil. ${ }^{3}$ Programa de Pós-Graduação em Química, Universidade Federal do Maranhão, São Luís, MA 64080-040, Brazil.

Received: 25 August 2020 Accepted: 16 January 2021

Published online: 25 January 2021

References

1. Shaw AJ (2009) Bryophyte species and speciation. In: Goffinet B, Shaw AJ (eds) Bryophyte ecology. Cambridge University Press, Cambridge, pp 445-485

2. Costa DP, Peralta DF (2015) Bryophytes diversity in Brazil. Rodriguésia 66:1063-1071. https://doi.org/10.1590/2175-7860201566409

3. Olsson S, Enroth J, Huttunen S, Quandt D (2016) Phylogeny of Neckeropsis and Himantocladium (Neckeraceae, Bryophytina). Bry Div Evo 38:53-70. https://doi.org/10.11646/bde.38.2.4

4. Missouri B, Garden, https://www.tropicos.org/name/35172262, accessed July 2020

5. Flora do Brasil (2015) http://floradobrasil.jbrj.gov.br/jabot/FichaPublicaTax onUC/FichaPublicaTaxonUC.do?id=FB96582

6. Asakawa Y, Ludwiczuk A, Nagashima F (2013) Phytochemical and biological studies of bryophytes. Phytochemistry 91:52-80. https://doi. org/10.1016/j.phytochem.2012.04.012

7. Asakawa Y, Ludwiczuk A (2018) Chemical constituents of bryophytes: structures and biological activity. J Nat Prod 81:641-660. https://doi. org/10.1021/acs.jnatprod.6b01046

8. Cansu TB, Yayli B, Ozdemir T, Batan N, Karaoglu SA, Yayli N (2013) Antimicrobial activity and chemical composition of the essential oils of mosses Hylocomium splendens (Hedw.) Schimp. and Leucodon sciuroides (Hedw.) Schwägr.) growing in Turkey. Turk J Chem 37:213-219. https://doi. org/10.3906/kim-1204-72

9. Valarezo E, Vidal V, Calva J, Jaramillo SP, Febres JD, Benetez A (2018) Essential oil constituents of mosses species from Equador. J Essent Oil Bear Plants 21:189-197. https://doi.org/10.1080/0972060X.2018.1432420 
10. Pejin B, Vujisic L, Sabovljevic M, Tesevic V, Vajs V (2011) Preliminary data on essential oil of the moss Rhodobryum ontariense (Kindb.) Kindb. Cryptogamie Bryologie 32:113-117. https://doi.org/10.7872/cryb.v32. iss 1.2011 .113

11. Wurzenberger M, Grosch W (1984) The formation of 1-octen-3-ol from the 10-hydroperoxide isomer of linoleic acid by a hydroperoxide lyase in mushrooms (Psalliota bispora). Biochem Biophys Acta 794:25-30

12. Lu Y, Eiriksson FF, Thorsteinsdóttir M, Simonsen HT (2019) Valuable fatty acids in Bryophytes-production, biosynthesis, analysis and applications. Plants 8:524. https://doi.org/10.3390/plants8110524

13. Croisier M, Rempt M, Pohnert G (2010) Survey of volatile oxylipins and their biosynthetic precursors in bryophytes. Phytochemistry 71:574-580. https://doi.org/10.1016/j.phytochem.2009.12.004

14. Cansu TB, Ozdemir T, Batan N, Yayli B, Karaoglu SA, Yayli N (2014) Essential oil analysis and antimicrobial activity of Neckera complanata (Hedw.) Huebener and Neckera crispa Hedw. (Neckeraceae) grown in Turkey. Asian J Chem 26:1-4. https://doi.org/10.14233/ajchem.2014.15618a

15. Pinheiro MFS, Lisboa RCL, Brazão RV (1989) Contribuição ao estudo de Briófitas como fontes de antibióticos. Acta Amazonica 19:139-145.18

16. Vidal CAS, Sousa EO, Rodrigues FFG, Campos AR, Lacerda SR, Costa JGM (2012) Phytochemical screening and synergistic interactions between aminoglycosides, selected antibiotics and extracts from the bryophyte Octobepharum albidum Hedw. (Calymperaceae). Arch Biol Sci 64:465-470. https://doi.org/10.2298/ABS1202465V

17. Costa DP, Amado-Filho GM, Pereira RC, Paradas WC, Miyataka H, Okamoto Y, Asakawa Y (2018) Diversity of secondary metabolites in the liverwort Syzygiella rubricaulis (Nees) Stephani (Jamesoniellaceae, Marchantiophyta) from neotropical high mountains. Chem Biodiver 15:1-7. https:// doi.org/10.1002/cbdv.201800239 e1800239.

18. Yano O (1984) Técnicas de coleta, herborização e preservação de material botânico. In: Fidalgo O, Bononi V (eds) Briófitas. Instituto de Botânica, Estado de São Paulo, São Paulo

19. Likens ST, Nickerson GB (1964) Detection of certain hop oil constituents in brewing products. Am Soc Brew Chem 22:5-13

20. NIST - National Institute of Standards and Technology (2014) Mass Spectral Library (NIST/EPA/NIH, v.2.0d). The NIST Mass Spectrometry Data Center, Gaithersburg

21. Mondello L (2011) FFNSC 2: flavors and fragrances of natural and synthetic compounds, mass spectral database. John Wiley \& Sons Inc., New York

22. van den Dool H, Kratz P (1963) A generalization of the retention index system including linear temperature programmed gas - liquid partition chromatography. J Chromatogr A 11:463-471. https://doi.org/10.1016/ S0021-9673(01)80947-X

23. Adams RP (2007) Identification of essential oil components by gas chromatography/mass spectrometry. Allured Publishing Corporation, Carol Stream
24. Feussner I, Wasternach C (2002) The lipoxygenase pathway. Ann Rev Plant Biol 53:275-297. https://doi.org/10.1146/annurev.arplant.53.10030 1.135248

25. Kihara H, Tanaka M, Yamato KT, Horibata A, Yamada A, Kita S, Ishizaki K, Kajikawa M, Fukusawa H, Kohchi T, Akakabe Y, Matsui K (2014) Arachidonic acid-dependent carbon-eight volatile synthesis from wounded liverwort (Marchantia polymorpha). Phytochemistry 107:42-49. https:// doi.org/10.1016/j.phytochem.2014.08.008

26. Chen F, Ludwiczuk A, Wei G, Chen X, Crandall-Stotler B, Bowman JL (2018) Terpenoid secondary metabolites in bryophytes: chemical diversity, biosynthesis and biological functions. Crit Rev Plant Sci 37:210-231. https ://doi.org/10.1080/07352689.2018.1482397

27. Valarezo E, Tandazo O, Galán K, Rosales J, Benítez A (2020) Volatile metabolites in liverworts of Equador. Metabolites 10:92. https://doi.org/10.3390/ metabo 10030092

28. Asakawa Y, Inoue H (1984) Studies on cryptogams in Southern Chile (Inoue H., ed.), and 117. Kenseisha Publishing Co., Tokyo, p 109 in.

29. Asakawa Y, Tada Y, Hashimoto T (1994) Naphthalene derivatives from the New Zealand liverwort, Wettsteinia schusterana. Phytochemistry 35:1555-1557

30. Kiang F-M, Chang S-J, Wu C-L (1994) Naphthalene and isocoumarin derivatives from the liverwort Wettsteinia inversa. Phytochemistry 37:1459-1461

31. Rycroft DS, Cole WJ, Rong S (1998) Highly oxygenated naphthalenes and acetophenones from the liverwort Adelanthus decipiens from the British Isles and South America. Phytochemistry 48:1351-1356

32. Tawfik MM, Yamato KT, Kohchi T, Koeduka T, Matsui K (2017) n-Hexanal and (Z)-3-hexenal are generated from arachidonic acid and linolenic acid by a lipoxygenase in Marchantia polymorpha L. Biosci Biotech Biochem 81:1148-1155. https://doi.org/10.1080/09168451.2017.1285688

33. Li L, Zhao J (2009) Determination of the volatile composition of Rhodobryum giganteum (Schwaegr.) Par. (Bryaceae) using solid-phase microextraction and chromatography/mass spectrometry (GC/MS). Molecules 14:2195-2201. https://doi.org/10.3390/molecules 14062195

34. Üçüncü O, Cansu TB, Özdemir T, Karaoglu SA, Yayli N (2010) Chemical composition and antimicrobial activity of the essential oils of mosses (Tortula muralis Hedw., Homalothecium lutescens (Hedw.) H Rob., Hypnum cupressiforme Hedw., and Pohlia nutans (Hedw.) Lindb. from Turkey. Turk J Chem 34:825-834. https://doi.org/10.3906/kim-1002-62

35. Yayintas OT, Sogut O, Konialioglu S, Yilmaz S, Tepeli B (2017) Antioxidant activities and composition of different extracts of mosses gathered from Turkey. AgroLife Sci J 6:205-213

\section{Publisher's note}

Springer Nature remains neutral with regard to jurisdictional claims in published maps and institutional affiliations.
Ready to submit your research? Choose BMC and benefit from:

- fast, convenient online submission

- thorough peer review by experienced researchers in your field

- rapid publication on acceptance

- support for research data, including large and complex data types

- gold Open Access which fosters wider collaboration and increased citations

- maximum visibility for your research: over $100 \mathrm{M}$ website views per year

At BMC, research is always in progress.

Learn more biomedcentral.com/submissions 